Abstracta Iranica

Revue bibliographique pour le domaine irano-aryen

Volume 37-38-39 | 2018

Comptes rendus des publications de 2014-2016

\title{
Rika Gyselen. « Realia for Sasanian history: Mint networks »
}

Julien Cuny

\section{OpenEdition}

1 Journals

\section{Édition électronique}

URL : http://journals.openedition.org/abstractairanica/46325

DOI : 10.4000/abstractairanica.46325

ISBN : 1961-960X

ISSN : 1961-960X

Éditeur :

CNRS (UMR 7528 Mondes iraniens et indiens), Éditions de l'IFRI

Référence électronique

Julien Cuny, «Rika Gyselen. « Realia for Sasanian history: Mint networks » », Abstracta Iranica [En ligne], Volume 37-38-39 | 2018, document 42, mis en ligne le 30 décembre 2018, consulté le 02 octobre 2020. URL : http://journals.openedition.org/abstractairanica/46325 ; DOI : https://doi.org/ 10.4000/abstractairanica.46325

Ce document a été généré automatiquement le 2 octobre 2020.

Tous droits réservés 


\title{
Rika Gyselen. « Realia for Sasanian history: Mint networks »
}

\author{
Julien Cuny
}

\section{RÉFÉRENCE}

Rika Gyselen. « Realia for Sasanian history: Mint networks » in A. Krasnowolska, R. Rusek-Kowalska (eds.). Studies on the Iranian World I: Before Islam (7th European Conference of Iranian Studies September 2011). Krakow: Jagiellonian University Press, 2015, p. 207-218

1 Réflexions méthodologiques sur les interprétations historiques possibles déduites de la reconstitution des réseaux d'ateliers monétaires dans l'empire sassanide. Ceux-ci sont connus par leurs sigles, d'autres sont restitués sur des critères stylistiques, et sont d'abord datés par règne puis à l'année près à partir du second règne de Kawād, ca. 500 de n.è. L'A. exprime une saine prudence sur l'argument $a$ silentio d'un atelier non attesté à une période donnée. Elle illustre son propos par divers exemples, tirés de l'analyse des ateliers des régions de l'est de l'empire.

\section{AUTEURS}

\section{JULIEN CUNY}

Conservateur au Musée du Louvre, Paris 